Article

\title{
Biocatalytic Approach to Chiral $\beta$-Nitroalcohols by Enantioselective Alcohol Dehydrogenase-Mediated Reduction of $\alpha$-Nitroketones
}

\author{
Francesca Tentori ${ }^{1,+}{ }^{t}$ Elisabetta Brenna ${ }^{1,2, *}$ (D), Danilo Colombo ${ }^{1}$, Michele Crotti ${ }^{1}$, \\ Francesco G. Gatti ${ }^{1}$ (D), Maria Chiara Ghezzi ${ }^{1}$ and Giuseppe Pedrocchi-Fantoni ${ }^{2}$ \\ 1 Politecnico di Milano, Dipartimento di Chimica, Materiali e Ingegneria Chimica, Via Mancinelli 7, \\ Milano I-20131, Italy; francesca.tentori@polimi.it (F.T.); danilo.colombo@polimi.it (D.C.); \\ michele.crotti@polimi.it (M.C.); francesco.gatti@polimi.it (F.G.G.); maria.ghezzi@studenti.unimi.it (M.C.G.) \\ 2 Istituto di Chimica del Riconoscimento Molecolare-CNR, Via Mancinelli 7, Milano I-20131, Italy; \\ giuseppe.pedrocchi@polimi.it \\ * Correspondence: mariaelisabetta.brenna@polimi.it; Tel.: +39-02-2399-3077 \\ + With the exception of the first author, the others are listed in alphabetical order.
}

Received: 12 July 2018; Accepted: 25 July 2018; Published: 29 July 2018

\begin{abstract}
Chiral $\beta$-nitroalcohols are important building blocks in organic chemistry. The synthetic approach that is based on the enzyme-mediated reduction of $\alpha$-nitroketones has been scarcely considered. In this work, the use of commercial alcohol dehydrogenases (ADHs) for the reduction of aromatic and aliphatic nitroketones is investigated. High conversions and enantioselectivities can be achieved with two specific ADHs, affording either the $(S)$ or $(R)$-enantiomer of the corresponding nitroalcohols. The reaction conditions are carefully tuned to preserve the stability of the reduced product, and to avoid the hydrolytic degradation of the starting substrate. The further manipulation of the enantioenriched nitroalcohols into Boc-protected amminoalcohols is also described.
\end{abstract}

Keywords: nitroketone; reduction; alcohol-dehydrogenase; enantioselectivity

\section{Introduction}

Chiral $\beta$-nitroalcohols 1 (Scheme 1) are relevant synthetic targets in organic chemistry. They are employed as key intermediates for the preparation of a wide range of biologically active natural products and active pharmaceutical ingredients [1-5], especially because they can be readily converted into chiral $\beta$-aminoalcohols 2 by reduction of the nitro moiety.

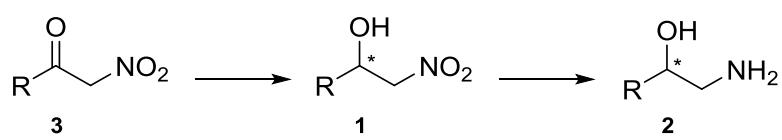

Scheme 1. Synthesis of $\beta$-amminoalcohols 2 through $\beta$-nitroalcohols 1 as intermediates

The most common approach to compounds $\mathbf{1}$ is represented by the enantioselective Henry (nitroaldol) reaction between aldehydes and nitromethane, which is catalysed by metal complexes or organocatalysts [1,6-16].

During the past decade, the search for greener and more sustainable synthetic procedures has promoted the investigation of biocatalysed strategies for the synthesis of enantiopure $\beta$-nitroalcohols [17]. Several examples of kinetic resolution of racemic compounds 1 catalysed by hydrolases have been reported in the literature [7]. It has also been discovered that some hydroxynitrile 
lyases (HNLs) are able to promote the enantioselective addition of nitromethane to aldehydes, such as the (S)-selective HNLs from Hevea brasiliensis and from Manihot esculenta [18-20], and the (R)-selective HNLs from Arabidopsis thaliana [21], Acidobacterium capsulatum, and Granulicella tundricula [22]. These reactions are generally characterized by long reaction times, and strong substrate dependence.

Another possible enzymatic approach, which has received scarce consideration until now, is represented by the bioreduction of $\alpha$-nitroketones 3 . Only a few papers on this topic are present in the literature. In 1987 [23], the baker's yeast reduction of 3-methyl-3-nitro-2-butanone to the (S)-enantiomer of corresponding alcohol (enantiomeric excess $=$ ee $>96 \%$ ) in $57 \%$ yield was described. A few years later, Moran et al. [24] investigated the reduction of $\alpha$-nitroacetophenone (3a. $R=P h$ ) in fermenting baker's yeast. Only $6 \%$ of nitroalcohol $1 \mathrm{a}(\mathrm{R}=\mathrm{Ph})$ could be isolated, with benzoic acid being the main product of the biotransformation (27\%). According to the authors, the formation of benzoic acid was due to the retro-Henry degradation of nitroalcohol 1a to benzaldehyde, followed by oxidation. In 2008, Kroutil et al. [25] reported on the conversion of 1-nitro-3-phenylpropan-2-one and 1-nitro-2-octanone into the enantiopure (S)-nitroalcohols in $47 \%$ and $75 \%$ yield, respectively, by using the lyophilized cells of Comomonas testoteroni. Recently [26], the whole cells of Candida parapsilosis ATCC 7330 were employed to catalyse the enantioselective reduction of some aliphatic derivatives 3 (only $R=$ alkyl) in water with ethanol as a cosolvent, at room temperature, and in $4 \mathrm{~h}$ reaction time (conversion yields $54-76 \%$, ee $=8.2-81 \%$ ). The formation of the $(R)$ or $(S)$ enantiomer of the corresponding nitroalcohol depended upon the nature of the $\mathrm{R}$ group.

The scarcity of experimental data on the bioreduction of $\alpha$-nitroketones, especially for aromatic derivatives, and the current need for biocatalysed synthesis of chiral building blocks for pharmaceutical applications [27-31] led us to investigate the use of commercial alcohol dehydrogenases for the enantioselective reduction of aryl and alkyl $\alpha$-nitroketones 3 in controlled reaction conditions. We also studied the further manipulation of specific nitroalcohols $\mathbf{1}$ to prepare aminoalcohols $\mathbf{2}$, which have been already employed as key intermediates for the synthesis of active pharmaceutical ingredients, such as levamisole and $(R)$-tembamide.

\section{Results and Discussion}

\subsection{Synthesis of Nitroketones $\mathbf{3}$ and Biocatalysed Reduction to Derivatives $\mathbf{1}$}

Nitroketones 3a-o (Scheme 2) were synthesized according to the literature by derivatization of the corresponding carboxylic acids with carbonyldiimidazole, followed by reaction with the sodium salt of nitromethane, which was obtained in turn by deprotonation of nitromethane with $\mathrm{NaH}$ [32].

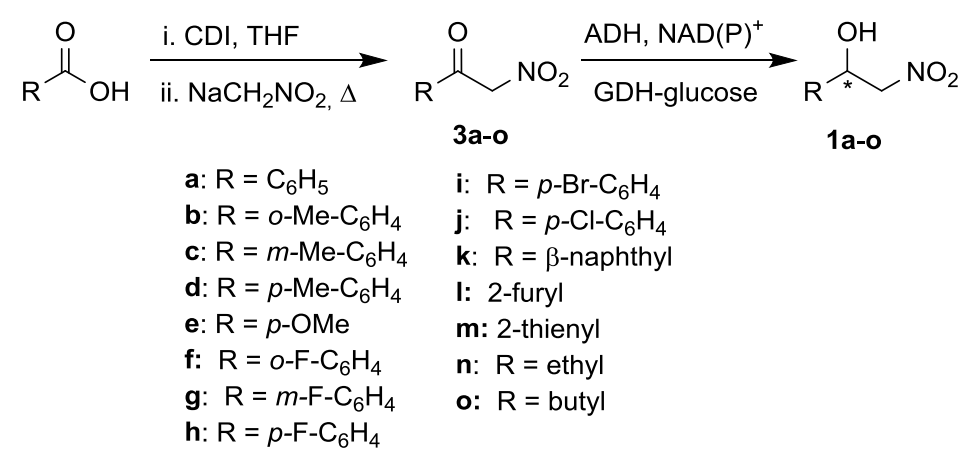

Scheme 2. Synthesis and biocatalysed reduction of nitroketones 3a-o.

Before starting the alcohol dehydrogenases (ADH) screening, the stability of derivatives 1 was investigated in buffer solutions at $\mathrm{pH}=5,7$, and 9 for $4-18 \mathrm{~h}$ at $25^{\circ} \mathrm{C}$, using compound $1 \mathrm{a}$ as a model and DMSO as a co-solvent. As expected, nitroalcohol 1a resulted to be unstable towards retro-Henry reaction in basic and neutral medium: conversion into benzaldehyde was complete at $\mathrm{pH}=7$ and 9 
after $18 \mathrm{~h}$. At $\mathrm{pH}=5$ no benzaldehyde was observed. Thus, $\mathrm{pH}=5$ was selected for the investigation of the biocatalysed reduction of compound 3a, using a panel of 18 commercial alcohol dehydrogenases (from Evoxx). The catalytic NADPH or NADH cofactor was recycled with glucose dehydrogenase (GDH from Bacillus megaterium), and glucose was employed as a sacrificial co-substrate. The reactions were performed in acetate buffer solution $(\mathrm{pH}=5)$ with $1 \%$ DMSO, monitored by TLC, and usually stopped after $4-5 \mathrm{~h}$. The results of the screening experiments are collected in Table S1. Conversion were evaluated by ${ }^{1} \mathrm{H}$ NMR spectroscopy and the enantiomeric excess values of the reduced products were determined by HPLC analysis on a chiral stationary phase. GC-analysis could not be used because nitroalcohol 1a undergoes partial thermal degradation to benzaldehyde.

During this screening, benzaldehyde was never detected in the final reaction mixture, while the formation of benzoic acid was observed in a variable amount: from $4-6 \%$ in the most effective reductions of 3a with ADH270 and 440, to nearly $30 \%$ in those reactions in which no nitroalcohol was formed. In order to explain the formation of benzoic acid, the stability of compound 3a was investigated in buffer solution $(\mathrm{pH}=5)$, in the presence of $1 \% \mathrm{DMSO}, \mathrm{GDH}, \mathrm{NAD}(\mathrm{P})^{+}$, without adding the $\mathrm{ADH}$, for 4 and $18 \mathrm{~h}$ at $25{ }^{\circ} \mathrm{C}$. Partial degradation (35\%) to the carboxylic acid was observed after $4 \mathrm{~h}$, while the complete conversion into benzoic acid was achieved after $18 \mathrm{~h}$. A search in the literature showed that Pearson et al. [33] had described the hydrolytic cleavage of nitroketone 3a to the corresponding carboxylic acid in dioxane-water solution and the possibility to suppress this side-reaction only in strong mineral acid solution. In the evaluation of the molar percentages of the reduced product 1a reported in Table S1, as calculated by ${ }^{1} \mathrm{H}$ NMR analysis of the final mixture, the formation of the carboxylic acid was taken into account. The integrals of the following well-separated signals were employed: (i) the doublet of doublets of the $\mathrm{CH}-\mathrm{OH}$ of $\mathbf{1 a}$ (one hydrogen atom); (ii) the singlet of the $\mathrm{CH}_{2}$ of $3 \mathbf{a}$ (two hydrogen atoms); and, (iii) the doublet of the two aromatic hydrogen atoms adjacent to the $\mathrm{COOH}$ group of benzoic acid.

Only eight of the eighteen screened ADHs could catalyze the reduction of nitroketone 3a. Prolonged reaction times did not improve the yield in the reduction product, instead promoted the extensive hydrolysis of unreacted starting 3a. The ADHs giving the best results in terms of both conversion and enantioselectivity, i.e., $\mathrm{ADH} 270,440$ and 441, were employed to investigate the reduction of the whole set of nitroketones $\mathbf{3 b} \mathbf{b}-\mathbf{o}$. The results are reported in Figure 1 and Table S2. The absolute configuration of all the nitroalcohols $\mathbf{1 a - 0}$ could be established by a comparison of the corresponding HPLC analyses on chiral stationary phase with those reported in the literature in the same experimental conditions (See Supplementary Materials).

$(R)$-Nitroalcohols were invariably obtained in the presence of $\mathrm{ADH} 440$, while opposite enantioselectivity were observed with either ADH270 or ADH441. In the reduction of 2-furyl and 2-thienyl derivatives $\mathbf{3 1}$ and $\mathbf{3 m}$, obtaining the (S)-nitroalcohol with ADH440 and the (R)-enantiomer with ADH270, and 441 does not represent an inversion of enantioselectivity with respect to the reductions of the other substrates. It is a consequence of the fact that the priority order of the substituents around the stereogenic centre is different for the presence of the heteroaromatic ring. The only real inversions of configuration were observed in the reduction of $3 \mathbf{f}\left(\mathrm{R}=o-\mathrm{F}-\mathrm{C}_{6} \mathrm{H}_{4}\right)$ and $\mathbf{3 n}$ ( $\mathrm{R}=$ ethyl) with ADH441 and 270, respectively, affording the corresponding $(R)$-enantiomers with ee $=43$ and $80 \%$.

The best results were achieved while using ADH440 as a catalyst (Figure 1). This enzyme promoted the conversion of nitroketones $\mathbf{3}$ into the $(R)$-enantiomer of nitroalcohols $\mathbf{1}$ with high yields ( $c=79-99 \%$ ) and very good ee values in the range $92-99 \%$ for most of the substrates. Enantioselectivity that was slightly lower $90 \%$ was observed in the quantitative reduction of $3 \mathrm{c}\left(\mathrm{R}=m-\mathrm{Me}-\mathrm{C}_{6} \mathrm{H}_{4}\right.$, ee $\left.=84 \%\right)$ and 31 ( $R=2$-furyl, ee $=71 \%)$. Only in the case of ethyl derivative $3 \mathrm{n}$, the corresponding reduced product was obtained in racemic form. 

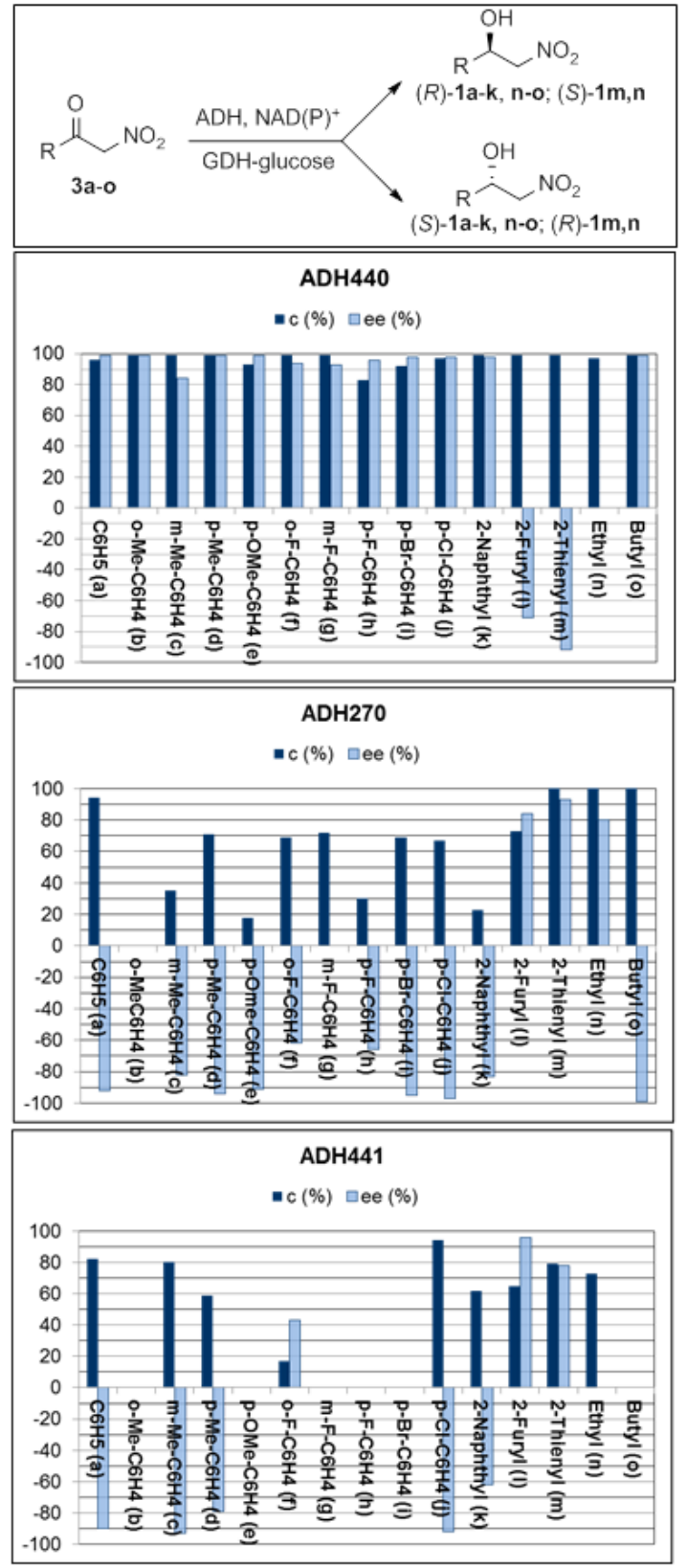

Figure 1. Alcohol dehydrogenases (ADH)-mediated reduction of nitroketones $3 \mathbf{a}-\mathbf{o}$ to nitroalcohols 1a-o (preliminary screening). For graphic reasons the ee values of $(R)$-enantiomers are represented as positive values, those of $(S)$-enantiomers are given as negative: $5 \mathrm{mM}$ substrate, $16 \mathrm{mM}$ glucose, $\mathrm{ADH}$, glucose dehydrogenase (GDH), NAD(P) ${ }^{+}, 1 \%$ DMSO, acetate buffer $\mathrm{pH} 5.0,25{ }^{\circ} \mathrm{C}, 4-5 \mathrm{~h}$; conversion (c, \%) calculated by ${ }^{1} \mathrm{H}$ NMR spectroscopy as molar percentage of the nitroalcohol 1 in the final reaction mixture after 4-5 h, taking into account the unreacted nitroketone 3 , and the carboxylic acid obtained upon nitroketone hydrolysis; enantiomeric excess (ee, \%) calculated on the basis of HPLC analysis on a chiral stationary phase.

ADH270 gave the (S)-enantiomer of the reduced product in all the bioreductions, with the exception of the reaction of compound $3 \mathrm{n}$ (Figure $1, \mathrm{R}=$ ethyl), affording $(R)-\mathbf{1 n}$ (ee $=80 \%$ ). The highest ee values (91-99\%) were obtained in the transformation of para-substituted nitroketones 3d $\left(\mathrm{R}=p-\mathrm{Me}-\mathrm{C}_{6} \mathrm{H}_{4}\right.$, ee $\left.=94 \%\right), 3 \mathbf{e}\left(\mathrm{R}=p-\mathrm{OMe}-\mathrm{C}_{6} \mathrm{H}_{4}\right.$, ee = 91\%), 3i $\left(\mathrm{R}=p-\mathrm{Br}_{-} \mathrm{C}_{6} \mathrm{H}_{4}\right.$, ee = 95\%), $3 \mathbf{j}$ $\left(\mathrm{R}=p-\mathrm{Cl}-\mathrm{C}_{6} \mathrm{H}_{4}, \mathrm{ee}=97 \%\right)$, and derivatives 3a $(\mathrm{R}=$ phenyl, ee $=92 \%), 3 \mathrm{~m}(\mathrm{R}=2$-thienyl, ee $=93 \%)$, and $3 \mathbf{o}(\mathrm{R}=$ butyl, ee $=99 \%)$. Enantioselectivity in the range $80-84 \%$ was achieved in the reduction of 
compounds 3c $\left(\mathrm{R}=m\right.$-Me- $\mathrm{C}_{6} \mathrm{H}_{4}$, ee $\left.=82 \%\right), 3 \mathrm{k}(\mathrm{R}=2$-naphthyl, ee $=83 \%), 31(\mathrm{R}=2$-furyl, ee $=84 \%)$, and $3 \mathrm{n}(\mathrm{R}=$ ethyl, ee $=80 \%)$, while modest ee values could be obtained with fluoro derivatives $3 \mathrm{f}$ $\left(\mathrm{R}=o-\mathrm{F}-\mathrm{C}_{6} \mathrm{H}_{4}, \mathrm{ee}=62 \%\right)$, and $3 \mathrm{~h}\left(\mathrm{R}=p-\mathrm{F}-\mathrm{C}_{6} \mathrm{H}_{4}\right.$, ee $\left.=66 \%\right) . m$-Fluoro nitroketone $3 \mathrm{~g}$ was converted into a racemic nitroalcohol. Only substrate $3 \mathbf{b}\left(\mathrm{R}=o-\mathrm{Me}-\mathrm{C}_{6} \mathrm{H}_{4}\right)$ was recovered unreacted.

When ADH441 was employed as a catalyst (Figure 1), the relevant results were achieved in the reduction of $3 \mathbf{a}(\mathrm{R}=\mathrm{Ph}), 3 \mathbf{c}\left(\mathrm{R}=m-\mathrm{Me}-\mathrm{C}_{6} \mathrm{H}_{4}\right), \mathbf{3} \mathbf{j}\left(\mathrm{R}=p-\mathrm{Cl}-\mathrm{C}_{6} \mathrm{H}_{4}\right)$, and $3 \mathbf{l}(\mathrm{R}=2$-furyl $)$, affording the corresponding nitroalcohol with high enantiomeric purity (ee $=90,93,92$ and $96 \%$, respectively).

The results of this screening clearly show that ADH270 and 440 are the most effective catalysts for the preparation of both the enantiomers of nitroalcohols 1.

\subsection{Bioreductions of Nitroketones in Biphasic Medium}

In order to avoid the drawback of nitroketone hydrolysis, the use of a biphasic medium (buffer and organic solvent) was evaluated. No benzoic acid was observed when compound 3a was stirred in toluene/buffer or EtOAc/buffer mixtures for $24 \mathrm{~h}$ in the presence of GDH and NAD $(\mathrm{P})^{+}$without adding the $\mathrm{ADH}$. In the presence of $\mathrm{ADH} 440$ and $\mathrm{ADH} 270$ as catalysts, the reductions proceeded affording the results that are reported in Table 1 . Toluene resulted to be the solvent of choice, preserving nitroketone 3a from hydrolysis, still maintaining the activity of the ADH.

Table 1. ADH-mediated reduction of nitroketone 3a to nitroalcohol 1a in biphasic system ${ }^{\mathrm{a}}$.

\begin{tabular}{rccc}
\hline ADH $^{\mathbf{1}}$ & Organic Solvent & Conversion $^{\mathbf{2}} \mathbf{( \% )}$ & Ee $^{\mathbf{3}}(\mathbf{\%})$ \\
\hline 270 & AcOEt & - & - \\
440 & AcOEt & 68 & $98(R)$ \\
270 & toluene & 88 & $95(S)$ \\
440 & toluene & 99 & $97(R)$ \\
\hline
\end{tabular}

${ }^{1}$ Total volume $4 \mathrm{~mL}$ (organic solvent/water 1/1), $6 \mathrm{mM}$ substrate, $20 \mathrm{mM}$ glucose, ADH (2 $\left.\mathrm{mg}\right), \mathrm{GDH}(1 \mathrm{mg})$, $\mathrm{NAD}(\mathrm{P})^{+}(0.25 \mathrm{mM})$, acetate buffer $\mathrm{pH} 5.0,25{ }^{\circ} \mathrm{C}, 24 \mathrm{~h} ;{ }^{2}$ conversion calculated on the basis of the ${ }^{1} \mathrm{H}$ NMR spectrum of the crude mixture after $24 \mathrm{~h} ;{ }^{3}$ enantiomeric excess calculated on the basis of HPLC analysis on a chiral stationary phase.

The ADH-mediated reduction of model nitroketone $3 \mathbf{a}$ was also investigated in 1:1 toluene-water (buffer $\mathrm{pH}=5$ ) at $25^{\circ} \mathrm{C}$ with $\mathrm{ADH} 270$ and 440 in order to increase both substrate loading $(\mathrm{mg} / \mathrm{mL}$ ) and substrate to enzyme ratio $(\mathrm{mg} / \mathrm{mg}$ ). The corresponding conversions, determined after $24 \mathrm{~h}$ reaction time by ${ }^{1} \mathrm{H}$ NMR spectroscopy, are reported in Table 2.

Table 2. Effect of substrate concentration and substrate/enzyme ratio on conversion for the ADH-mediated reduction of $3 \mathbf{a}$.

\begin{tabular}{cccc}
\hline ADH $^{\mathbf{1}}$ & [Substrate](mg/mL) & Substrate/Enzyme(mg/mg) & Conversion $^{\mathbf{2}} \mathbf{( \% )}$ \\
\hline \multirow{4}{*}{440} & 1 & 2.0 & 99 \\
& 1 & 8.0 & 94 \\
2 & 2.0 & 95 \\
2 & 8.0 & 91 \\
3 & 8.0 & 94 \\
3 & 24.0 & 80 \\
\hline 1 & 2.0 & 88 \\
270 & 1 & 3.0 & 67 \\
& 2 & 2.0 & 84 \\
& 2 & 3.0 & 74 \\
& 3 & 3.0 & 73 \\
3 & 4.0 & 58 \\
\hline
\end{tabular}

${ }^{1}$ Total volume $4 \mathrm{~mL}$ (organic solvent/water 1/1), substrate, glucose (3.2 eq), $\mathrm{ADH}, \mathrm{GDH}, \mathrm{NAD}(\mathrm{P})^{+}(0.04$ eq), acetate buffer $\mathrm{pH} 5.0,25^{\circ} \mathrm{C}, 24 \mathrm{~h} ;{ }^{2}$ conversion calculated on the basis of the ${ }^{1} \mathrm{H}$ NMR spectrum of the crude mixture after $24 \mathrm{~h}$. 
ADH440 was found to be very effective in promoting the reduction of substrate 3a: in batch conditions, with a substrate concentration of $3 \mathrm{mg} / \mathrm{mL}$, conversion remained still satisfactory $(80 \%)$ when the enzyme concentration was decreased from $0.38 \mathrm{mg} / \mathrm{mL}$ (substrate/enzyme $=8$ ) to $0.12 \mathrm{mg} / \mathrm{mL}$ (substrate/enzyme $=24$ ).

ADH 270 showed less efficiency than ADH440 in these bioreductions. When substrate loading was increased to $3 \mathrm{mg} / \mathrm{mL}$ the use of $1 \mathrm{mg} / \mathrm{mL}$ enzyme (substrate/enzyme $=3$ ) afforded $73 \%$ conversion, while a further decrease of enzyme concentration to $0.75 \mathrm{mg} / \mathrm{mL}$ (substrate/enzyme $=4$ ) led only to $58 \%$ of reduced product.

\subsection{Synthesis of Boc-protected $\beta$-Aminoalcohols 2}

The conversion of $\beta$-nitroalcohols 1 into $\beta$-aminoalcohols 2 was investigated, in order to establish the synthetic potential of the ADH-mediated reduction of nitroketones 3 and highlight its value within organic chemistry procedures. Compounds $\mathbf{1 a}$ and $\mathbf{1 e}$ were employed as model substrates, since the corresponding amino derivatives $(S)$-2a and $(R)-2 \mathbf{e}$ are the key intermediates in the synthesis of active pharmaceutical ingredients, such as levamisole and $(R)$-tembamide (Scheme 3$)$.

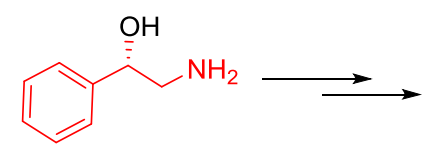

(S)-2a

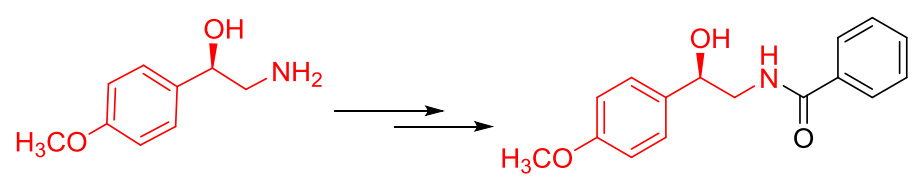

$(R)-2 e$

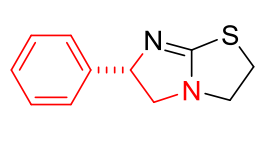

levamisole

$(R)$-tembamide

Scheme 3. Active pharmaceutical ingredients prepared starting from amino alcohols $(S)$-2a and (R)-2e.

Levamisole, which is the (S)-enantiomer of tetramisole, is a broad spectrum anthelmintic [34], which has found wide application in the treatment of worm infestations and in the elimination of intestinal parasites in both humans and animals. It is also one of the nonspecific immunomodulating agents that are used in clinical practice [35-37]. The known synthetic asymmetric approaches are based on the use of optically active phenylethylenediamine [38-41] or amino alcohol (S)-2a as intermediates [42].

$(R)-(-)$-Tembamide is a naturally occurring $\beta$-hydroxyamide isolated from various members of the Rutaceae family. This compound has been reported to have insecticide and adrenaline-like activity. Extracts of Aegle marmelos, containing tembamide, have been used in the Indian traditional medicine as a control for hypoglycemia [43]. Most of the enantioselective procedures to $(R)$-tembamide involve the use of the corresponding amino alcohol $(R)-2 \mathbf{e}$ as a key building block [44].

The nitro moiety of model compounds $(S)-\mathbf{1 a}$ and $(R)-\mathbf{1 e}$ was converted into the corresponding amino functionality by reaction with $\mathrm{NiCl}_{2} \cdot 6 \mathrm{H}_{2} \mathrm{O}$ and $\mathrm{NaBH}_{4}$ (Scheme 4 ), followed by treatment with $(\mathrm{Boc})_{2} \mathrm{O}$, in order to facilitate the isolation of the aminoalcohol from the reaction mixture. The reaction was fast and is characterized by complete conversion. The Boc derivatives could be recovered as solid compounds, and easily purified by crystallisation. The procedure was carried out directly in the reaction medium of the biocatalysed reaction, after removal of the aqueous phase, avoiding the isolation of the intermediate nitroalcohols, in order to achieve a one-pot chemo-catalysed conversion of nitroketones 3a and 3e into Boc-protected derivatives (S)-2a and (R)-2e, in 57 and 63\% isolation yields. 


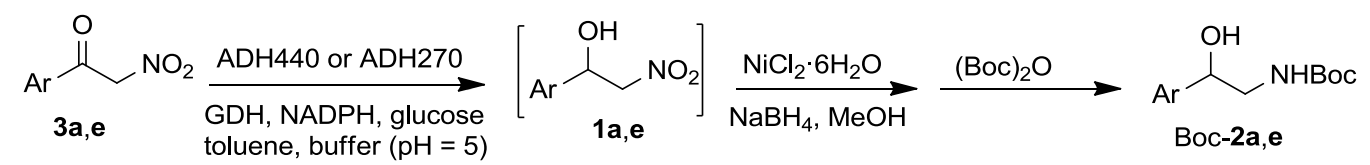

Scheme 4. Synthesis of Boc-protected derivatives 2.

\section{Materials and Methods}

\subsection{Sources of Enzymes}

GDH from Bacillus megaterium DSM509 (DSM, Heerlen, the Netherlands) was overexpressed in E. coli BL21 (DE3) strains harbouring the plasmid pKTS-GDH prepared according to standard molecular biology techniques. The enzyme was produced and purified, as described in the Supplementary Materials.

The complete set of ADHs was purchased from Evoxx (Monheim am Rhein, Germany).

\subsection{General Procedure for the ADH-Mediated Reduction of $\alpha$-Nitroketones 1a-o (Screening)}

A solution of the substrate in DMSO $(50 \mu \mathrm{L}, 500 \mathrm{mM})$ was added to an acetate buffer solution $(5 \mathrm{~mL}, 50 \mathrm{mM}, \mathrm{pH} 5.0)$ containing glucose $(80 \mu \mathrm{mol}), \mathrm{NADP}^{+}(1 \mu \mathrm{mol}$, Sigma-Aldrich, Milan, Italy) or $\mathrm{NAD}^{+}(1 \mu \mathrm{mol}$, Sigma-Aldrich, Milan, Italy) (according to the ADH preference), GDH (1.5 mg), and the required $\mathrm{ADH}$ ( $3 \mathrm{mg}$, Evoxx, Monheim am Rhein, Germany). The mixture was incubated for $4-5 \mathrm{~h}$ in an orbital shaker $\left(150 \mathrm{rpm}, 30^{\circ} \mathrm{C}\right)$. The solution was extracted with EtOAc $(2 \times 1 \mathrm{~mL}$, Sigma-Aldrich, Milan, Italy), centrifuging after each extraction $(15,000 \mathrm{~g}, 1.5 \mathrm{~min})$. The combined organic solutions were dried over anhydrous $\mathrm{Na}_{2} \mathrm{SO}_{4}$, and concentrated under reduced pressure. The residue was submitted to ${ }^{1} \mathrm{H}$ NMR analysis (Bruker, Milan, Italy) to determine conversion. Two replicates were performed for each biotransformation: no significant differences (less than $5 \%$ ) were observed for conversion and enantiomeric excess values.

The enantiomeric excess values of each nitroalcohol was determined by HPLC analysis (Agilent, Cernusco sul Naviglio, Italy) on a chiral stationary phase (See Supplementary Materials). The comparison of these HPLC analyses with those that were reported in the literature in the same experimental conditions (See Supplementary Materials) allowed for the absolute configuration of nitroalcohols 1a-o to be established.

\subsection{General Procedure for the Reduction of Nitroketone 3a in a Biphasic System Mediated by ADH440 and ADH270.}

A solution of nitroketone $3 \mathbf{a}(4 \mathrm{mg}, 25 \mu \mathrm{mol})$ in toluene $(2 \mathrm{~mL})$ was mixed with an acetate buffer solution $(2 \mathrm{~mL}, 50 \mathrm{mM}, \mathrm{pH}=5)$, containing glucose $(80 \mu \mathrm{mol}), \mathrm{NADP}^{+}(1 \mu \mathrm{mol}), \mathrm{GDH}(1 \mathrm{mg})$, and the required $\mathrm{ADH}(2 \mathrm{mg})$. The mixture was incubated for $24 \mathrm{~h}$ in an orbital shaker $\left(150 \mathrm{rpm}, 30^{\circ} \mathrm{C}\right)$. The mixture was extracted with EtOAc $(2 \times 1 \mathrm{~mL})$, centrifuging after each extraction $(15,000 \mathrm{~g}, 1.5 \mathrm{~min})$. The combined organic solutions were dried over anhydrous $\mathrm{Na}_{2} \mathrm{SO}_{4}$, and concentrated under reduced pressure. The residue was submitted to ${ }^{1} \mathrm{H}$ NMR analysis to determine conversion. Two replicates were performed for each biotransformation: no significant differences (less than $5 \%$ ) were observed for the conversion and enantiomeric excess values.

The same procedure was employed to investigate the effect on conversion due to substrate loading and substrate to enzyme ratio, by changing the amount of nitroketone and $\mathrm{ADH}$.

\subsection{General Procedure for the Conversion $\alpha$-Nitroketones 3a and 3e into Boc Protected Amino Alcohols 2a and $2 \mathbf{e}$}

The enantioselective reduction of the nitroketone was performed with the required $\mathrm{ADH}$ on 100 $\mathrm{mg}$ of nitroketone (20 mL of toluene, $20 \mathrm{~mL}$ of buffer $\mathrm{pH}=5,15 \mathrm{mg}$ of ADH440 or $35 \mathrm{mg}$ of ADH270, $10 \mathrm{mg} \mathrm{NADP}{ }^{+}, 7.5$ or $18 \mathrm{mg} \mathrm{GDH}, 150 \mathrm{mg}$ glucose), following the procedure already described in the previous paragraph for biotransformations in biphasic medium. After $24 \mathrm{~h}$, the aqueous phase was 
removed, methanol was added $(0.5 \mathrm{~mL})$, followed by the cautious addition of $\mathrm{NiCl}_{2} \cdot 6 \mathrm{H}_{2} \mathrm{O}(1 \mathrm{eq})$ and $\mathrm{NaBH}_{4}$ (3 eq) under vigorous stirring. After $30 \mathrm{~min},(\mathrm{Boc})_{2} \mathrm{O}(1.2 \mathrm{eq})$ was added. The mixture was stirred for $30 \mathrm{~min}$, filtered through a celite pad, and extracted with EtOAc. The organic layers were dried over anhydrous $\mathrm{Na}_{2} \mathrm{SO}_{4}$, and the residue was purified by crystallization from hexane-EtOAc.

\subsection{1. (S)-Tert-butyl (2-hydroxy-2-phenylethyl) carbamate ((S)-2a)}

From compound 3a (100 mg, $0.61 \mathrm{mmol})$, using ADH270, derivative $(S)$-2a was obtained (83 mg, $57 \%)$ : ee $(\mathrm{HPLC})=92 \%,[\alpha]_{\mathrm{D}}=+46.8\left(c 0.85, \mathrm{CHCl}_{3}\right)$ [lit. ref. [45] $[\alpha]_{\mathrm{D}}=+45.1 .\left(c 0.6, \mathrm{CHCl}_{3}\right)$ for $(S)-1 \mathrm{a}$ with ee $=93 \%$ ]; ${ }^{1} \mathrm{H}$ NMR $\left(\mathrm{CDCl}_{3}, 400 \mathrm{MHz}\right)[39]: \delta=7.40-7.27(\mathrm{~m}, 5 \mathrm{H}, \mathrm{ArH}), 4.92(\mathrm{br} \mathrm{s}, 1 \mathrm{H}, \mathrm{NH}), 4.83$ $(\mathrm{m}, 1 \mathrm{H}, \mathrm{CHOH}), 3.48(\mathrm{~m}, 1 \mathrm{H}, \mathrm{CHN}), 3.26(\mathrm{~m}, 1 \mathrm{H}, \mathrm{CHN}), 3.01(\mathrm{br} \mathrm{s}, 1 \mathrm{H}, \mathrm{OH}), 1.45\left(\mathrm{~s}, 9 \mathrm{H},\left(\mathrm{CH}_{3}\right)_{3} \mathrm{C}\right)$; ${ }^{13} \mathrm{C} \mathrm{NMR}\left(\mathrm{CDCl}_{3}, 100.6 \mathrm{MHz}\right)[45]: \delta=157.1,142.0,128.6,127.9,126.0,80.0,74.0,48.5,28.5$; GC-MS (EI) $\mathrm{t}_{\mathrm{r}}=21.5 \mathrm{~min} m / z(\%)=181\left(\mathrm{M}^{+}-56,14\right), 107(100), 79(47), 57(100)$.

HPLC analysis [45]: Chiralcel OD, 95/5 hexane $/ i-\mathrm{PrOH}, 0.6 \mathrm{~mL} / \mathrm{min}, 215 \mathrm{~nm},(R)-2 \mathrm{a} \mathrm{t}_{\mathrm{r}}=19.1 \mathrm{~min}$, $(S)-2 a t_{r}=23.4 \mathrm{~min}$.

\subsection{2. (R)-Tert-butyl (2-hydroxy-2-(4-methoxyphenyl)ethyl) carbamate ((R)-2e)}

From compound 3e (100 mg, 0.51 mmol), using ADH440, derivative $(R)-2 \mathbf{e}$ was obtained $(86.3 \mathrm{~g}$, $63 \%)$ : ee $(\mathrm{HPLC})=96 \%,[\alpha]_{\mathrm{D}}=-37.7\left(\mathrm{c} 0.7, \mathrm{CHCl}_{3}\right) ;{ }^{1} \mathrm{H} \mathrm{NMR}\left(\mathrm{CDCl}_{3}, 400 \mathrm{MHz}\right)[46]: \delta=7.28$ $(\mathrm{d}, J=8.7 \mathrm{~Hz}, 2 \mathrm{H}, \mathrm{ArH}), 6.88(\mathrm{~d}, J=8.7 \mathrm{~Hz}, 2 \mathrm{H}, \mathrm{ArH}), 4.95(\mathrm{br} \mathrm{s}, 1 \mathrm{H}, \mathrm{NH}), 4.76(\mathrm{~m}, 1 \mathrm{H}, \mathrm{CHOH}), 3.80$ $\left(\mathrm{s}, 3 \mathrm{H}, \mathrm{OCH}_{3}\right), 3.43(\mathrm{~m}, 1 \mathrm{H}, \mathrm{CHN}), 3.23(\mathrm{~m}, 1 \mathrm{H}, \mathrm{CHN}), 3.00(\mathrm{br} \mathrm{s}, 1 \mathrm{H}, \mathrm{OH}), 1.44\left(\mathrm{~s}, 9 \mathrm{H},\left(\mathrm{CH}_{3}\right)_{3} \mathrm{C}\right)$; ${ }^{13} \mathrm{C} \mathrm{NMR}\left(\mathrm{CDCl}_{3}, 100.6 \mathrm{MHz}\right): \delta=159.4,157.0,134.1,127.2,114.1,79.9,73.2,55.4,48.5,28.5$; GC-MS (EI) $\mathrm{t}_{\mathrm{r}}=23.8 \mathrm{~min} \mathrm{~m} / \mathrm{z}(\%)=267\left(\mathrm{M}^{+}, 0.5\right), 211(5), 137(100), 109(15), 57(18)$.

HPLC analysis: Chiralcel OD, 95/5 hexane $/ i-\mathrm{PrOH}, 0.6 \mathrm{~mL} / \mathrm{min}, 215 \mathrm{~nm},(R)-\mathbf{2 a} \mathrm{t}_{\mathrm{r}}=26.9 \mathrm{~min}$, $(S)-\mathbf{2 a} \mathbf{t}_{\mathrm{r}}=34.9 \mathrm{~min}$.

\section{Conclusions}

The results that are reported in this work show that the biocatalytic reduction of $\alpha$-nitroketones 3 mediated by ADHs is a convenient and useful procedure for the synthesis of both the enantiomers of the corresponding $\beta$-nitroalcohols 1 with high enantiomeric purity. In particular, for the first time the reduction of aryl and heteroaryl $\alpha$-nitroketones $(R=$ aryl or heteroaryl $)$ has been successfully achieved by enzymatic catalysis, enlarging the known methods for the reduction of these compounds limited up to now to the asymmetric transfer hydrogenation in the presence of ruthenium [47], and iridium [48] chiral complexes, with formic acid as a reductant.

The bioreduction is performed under mild conditions (ambient temperature and pressure), with low energy consumption, at the expense of glucose, which is employed as a sacrificial substrate for the enzymatic regeneration of the cofactor. The enzymes catalyzing this transformation with either $(R)$ - and (S)-selectivity are commercially available, and they can be manipulated easily and safely. The use of a biphasic reaction medium with toluene as an organic solvent does not inhibit the activity of the selected ADHs, helps in preserving the starting substrate from hydrolytic degradation, and it improves work-up procedures. The further manipulation of nitroketones into aminoalcohols was carried out without isolation of the nitroalcohol intermediate, thus telescoping the synthetic sequence.

Future work will be devoted to increase the productivity of the reaction, for example, by immobilizing the most suitable $\mathrm{ADHs}$ on solid supports and performing the reaction in flow conditions.

Supplementary Materials: The following are available online at http:/ /www.mdpi.com/2073-4344/8/8/308/s1.

Author Contributions: E.B. conceived and designed the experiments; F.T., D.C. and M.C.G. performed the experiments and the structural characterization of compounds; E.B., M. C., F.G.G., and G.P.-F. analyzed the data and wrote the paper. 
Funding: The authors thank Regione Lombardia for the financial support to the fellowship of D.C. within the project VIPCAT (Value Added Innovative Protocols for Catalytic Transformations"-ID 228775).

Acknowledgments: To Professor Claudio Fuganti with gratitude.

Conflicts of Interest: The authors declare no conflict of interest.

\section{References}

1. Luzzio, F.A. The Henry reaction: recent examples. Tetrahedron 2001, 57, 915-945. [CrossRef]

2. Klingler, F.D. Asymmetric hydrogenation of prochiral amino ketones to amino alcohols for pharmaceutical use. Acc. Chem. Res. 2007, 40, 1367-1376. [CrossRef] [PubMed]

3. Takasu, T.; Ukai, M.; Sato, S.; Matsui, T.; Nagase, I.; Maruyama, T.; Sasamata, M.; Miyata, K.; Uchida, H.; Yamaguchi, O. Effect of (R)-2-(2-aminothiazol-4-yl)-4-\{2-[(2-hydroxy-2-phenylethyl)amino]ethyl\} acetanilide (YM178), a novel selective beta(3)-adrenoceptor agonist, on bladder function. J. Pharmacol. Exp. Ther. 2007, 321, 642-647. [CrossRef] [PubMed]

4. Hicks, A.; McCafferty, G.P.; Riedel, E.; Aiyar, N.; Pullen, M.; Evans, C.; Luce, T.D.; Coatney, R.W.; Rivera, G.C.; Westfall, T.D.; et al. GW427353 (solabegron), a novel, selective beta(3)-adrenergic receptor agonist, evokes bladder relaxation and increases micturition reflex threshold in the dog. J. Pharmacol. Exp. Ther. 2007, 323, 202-209. [CrossRef] [PubMed]

5. Blay, G.; Hernández-Olmos, V.; Pedro, J.P. Synthesis of (S)-(+)-sotalol and (R)-(-)-isoproterenol via a catalytic enantioselective Henry reaction. Tetrahedron 2010, 21, 578-581. [CrossRef]

6. Alvarez-Casao, Y.; Marques-Lopez, E.; Herrera, R.P. Organocatalytic enantioselective Henry reactions. Symmetry 2011, 3, 220-245. [CrossRef]

7. Palomo, C.; Oiarbide, M.; Laso, A. Recent advances in the catalytic asymmetric nitroaldol (Henry) reaction. Eur. J. Org. Chem. 2007, 2561-2574, 2561-2574. [CrossRef]

8. Marcelli, T.; van der Haas, R.N.S.; van Maarseveen, J.H.; Hiemstra, H. Asymmetric organocatalytic Henry reaction. Angew. Chem. Int. Ed. 2006, 45, 929-931. [CrossRef] [PubMed]

9. Shibazaki, M.; Kumagaya, N.; Nitabara, T. Preparation of Optically Active Anti-1,2-Nitroalcohols by Stereoselective Nitroaldol Reaction. Jpn. Kokai Tokkyo Koho JP 2009114071 A, 28 May 2009.

10. Shibazaki, M.; Matsunaga, S.; Handa, S. Preparation of Optically Active Anti-1,2-Nitroalcohols by Stereoselective Nitroaldol Reaction with Palladium Lanthanum-Schiff Base Complex Catalysts. Jpn. Kokai Tokkyo Koho JP 2009108012 A, 21 May 2009.

11. Ooi, T.; Uraguchi, D. Chiral Tetraaminophosphonium salts, catalyst for asymmetric synthesis and method for producing chiral beta Nitroalcohol. US 20090131716 A1, 21 May 2009.

12. Baxter, C.E.J. Preparation of $\left(1 R^{*}, 2 S^{*}\right)$-1-Phenyl-2-Nitroalcohols from Benzaldehyde and the Corresponding Nitroalkane in the Presence of Amine Catalysts. US 5750802 A, 12 May 1998.

13. Kodama, K.; Sugawara, K.; Hirose, T. Synthesis of chiral 1,3-diamines derived from cis-2-benzamidocyclohexane carboxylic acid and their application in the Cu-catalyzed enantioselective Henry reaction. Chem. Eur. J. 2011, 17, 13584-13592. [CrossRef] [PubMed]

14. Chinnaraja, E.; Arunachalam, R.; Subramanian, P.S. Enantio- and diastereoselective synthesis of beta-nitroalcohol via Henry reaction catalyzed by $\mathrm{Cu}(\mathrm{II}), \mathrm{Ni}(\mathrm{II}), \mathrm{Zn}(\mathrm{II})$ complexes of chiral BINIM ligands. ChemistrySelect 2016, 1, 5331-5338. [CrossRef]

15. Cwiek, R.; Niedziejko, P.; Kaluzia, Z. Synthesis of tunable diamine ligands with spiro indane-2,2-pyrrolidine backbone and their applications in enantioselective Henry reaction. J. Org. Chem. 2014, 79, 1222-1234. [CrossRef] [PubMed]

16. Angelin, M.; Vongvilai, P.; Fischer, A.; Ramström, O. Crystallization-driven asymmetric synthesis of pyridine-beta-nitroalcohols via discovery-oriented self-resolution of a dynamic system. Eur. J. Org. Chem. 2010, 2010, 6315-6318. [CrossRef]

17. Milner, S.E.; Moody, T.S.; Maguire, A.R. Biocatalytic approaches to the Henry (nitroaldol) reaction. Eur. J. Org. Chem. 2012, 2012, 3059-3067. [CrossRef]

18. Purkarthofer, T.; Gruber, K.; Gruber-Khadjawi, M.; Waich, K.; Skranc, W.; Mink, D.; Griengl, H. A biocatalytic henry reaction-the hydroxynitrile lyase from Hevea brasiliensis also catalyzes nitroaldol. Angew. Chem. Int. Ed. 2006, 45, 3454-3456. [CrossRef] [PubMed] 
19. Gruber-Khadjawi, M.; Purkarthofer, T.; Skranc, W.; Griengl, H. A biocatalytic Henry reaction-The hydroxynitrile lyase from Hevea brasiliensis also catalyzes nitroaldol reactions. Adv. Synth. Catal. 2007, 349, 1445-1450. [CrossRef]

20. Yuryev, R.; Purkarthofer, T.; Gruber, M.; Griengl, H.; Liese, A. Kinetic studies of the asymmetric Henry reaction catalyzed by hydroxynitrile lyase from Hevea brasiliensis. Biocatal. Biotransform. 2010, 28, 348-356. [CrossRef]

21. Fuhshuku, K.; Asano, Y. Synthesis of (R)-beta-nitro alcohols catalyzed by $R$-selective hydroxynitrile lyase from Arabidopsis thaliana in the aqueous-organic biphasic system. J. Biotechnol. 2011, 153, 153-159. [CrossRef] [PubMed]

22. Bekerle-Bogner, M.; Gruber-Khadjawi, M.; Wiltsche, H.; Wiedner, R.; Schwab, H.; Steiner, K. (R)-Selective nitroaldol reaction catalyzed by metal-dependent bacterial hydroxynitrile lyase. ChemCatChem 2016, 8, 2214-2216. [CrossRef]

23. Fujisawa, T.; Hayashi, H.; Kishioka, Y. Enantioselective Synthesis of Optically Pure Amino Alcohol Derivatives by Yeast Reduction. Chem. Lett. 1987, 16, 129-132. [CrossRef]

24. Brenelli, E.; de Carvalho, M.; Marques, M.; Moran, P.J.S.; Rodrigues, J.A.R.; Sorrilha, A.E.P.M. Enantioselective synthesis of $(R)-(-)$-phenylethanolamines using Baker's yeast reduction of some substituted methyl phenyl ketones. Indian J. Chem. 1992, 31B, 821-823.

25. Wallner, S.R.; Lavandera, I.; Mayer, S.F.; Öhrlein, R.; Hafner, A.; Edegger, K.; Faber, K.; Kroutil, W. Stereoselective anti-Prelog reduction of ketones by whole cells of Comamonas testosteroni in a substrate-coupled approach. J. Mol. Catal. B. 2008, 55, 126-129. [CrossRef]

26. Venkataraman, S.; Chadha, A. Enantio- \& chemo-selective preparation of enantiomerically enriched aliphatic nitro alcohols using Candida parapsilosis ATCC 7330. RSC Adv. 2015, 5, 73807-73813. [CrossRef]

27. Albarrán-Velo, J.; González-Martínez, D.; Gotor-Fernández, V. Stereoselective biocatalysis: A mature technology for the asymmetric synthesis of pharmaceutical building blocks. Biocatal. Biotransform. 2017, 36, 102-130. [CrossRef]

28. Brenna, E.; Crotti, M.; Gatti, F.G.; Monti, D.; Parmeggiani, F.; Pugliese, A.; Tentori, F. Biocatalytic synthesis of chiral cyclic gamma-oxoesters by sequential $\mathrm{C}-\mathrm{H}$ hydroxylation, alcohol oxidation and alkene reduction. Green Chem. 2017, 19, 5122-5130. [CrossRef]

29. Brenna, E.; Crotti, M.; Gatti, F.G.; Monti, D.; Parmeggiani, F.; Santangelo, S. Asymmetric bioreduction of beta-acylaminonitroalkenes: Easy access to chiral building blocks with two vicinal nitrogen-containing functional groups. ChemCatChem 2017, 9, 2480-2487. [CrossRef]

30. Brenna, E.; Cannavale, F.; Crotti, M.; De Vitis, V.; Gatti, F.G.; Migliazza, G.; Molinari, F.; Parmeggiani, F.; Romano, D.; Santangelo, S. Synthesis of enantiomerically enriched 2-hydroxymethylalkanoic acids by oxidative desymmetrisation of achiral 1,3-diols mediated by Acetobacter aceti. ChemCatChem 2016, 8, 3796-3803. [CrossRef]

31. Brenna, E.; Crotti, M.; Gatti, F.G.; Monti, D.; Parmeggiani, F.; Powell, R.W.; Santangelo, S.; Stewart, J.D. Opposite enantioselectivity in the bioreduction of (Z)-beta-aryl-beta-cyanoacrylates mediated by the tryptophan 116 mutants of Old Yellow Enzyme 1: synthetic approach to $(R)$ - and (S)-beta-aryl-gamma-lactams. Adv. Synth. Catal. 2015, 357, 1849-1860. [CrossRef]

32. Lindsay, V.N.G.; Lin, W.; Charette, A.B. Experimental evidence for the all-up reactive conformation of chiral rhodium(II) carboxylate catalysts: enantioselective synthesis of cis-cyclopropane alpha-amino acids. J. Am. Chem. Soc. 2009, 131, 16383-16385. [CrossRef] [PubMed]

33. Pearson, R.G.; Anderson, D.H.; Alt, L.L. Mechanism of the hydrolytic cleavage of carbon-carbon bonds. III. Hydrolysis of alpha-nitro and alpha-sulfonyl ketones. J. Am. Chem. Soc. 1955, 77, 527-529. [CrossRef]

34. Thienpont, D.C.I.; Vanparijs, O.; Raeymaekers, A.; Vandenberk, J.; Demoen, P.; Allewijn, F.; Marsboom, R.; Niemegeers, C.; Schellekens, K.; Janssen, P. Tetramisole (R 8299), a new, potent broad spectrum anthelmintic. Nature 1966, 209, 1084-1086. [CrossRef] [PubMed]

35. Moertel, C.G.; Fleming, T.T.; Macdonald, J.S.; Haller, D.G.; Laurie, J.A.; Tangen, C.M.; Ungerleider, J.S.; Emerson, W.A.; Tormey, D.C.; Glick, J.H.; et al. Fluorouracil plus levamisole as effective adjuvant therapy after resection of stage III colon carcinoma: a final report. Anal. Int. Med. 1995, 122, 321-326. [CrossRef]

36. Moertal, G.G.; Fleming, T.R.; Macdonald, J.S. Levamisole and fluorouracil for adjuvant therapy of resected colon-carcinoma. New Engl. J. Med. 1990, 322, 352-358. [CrossRef] [PubMed] 
37. Gwilt, P.; Tempero, M.; Kremer, A.; Connolly, M.; Ding, C. Pharmacokinetics of levamisole in cancer patients treated with 5-fluorouracil. Cancer Chemother. Pharmacol. 2000, 45, 247-251. [CrossRef] [PubMed]

38. Raeymaekers, A.H.M.; Roevens, L.F.C.; Janssen, P.A.J. The absolute configurations of the optical isomers of the broad spectrum anthelmintic tetramisole. Tetrahedron Lett. 1967, 8, 1467-1470. [CrossRef]

39. Choudhary, M.K.; Rajkumar Tak, R.; Kureshy, R.I.; Ansari, A.; Khan, N.H.; Abdi, S.H.R.; Bajaj, H.C. Enantioselective aza-Henry reaction for the synthesis of (S)-levamisole using efficient recyclable chiral $\mathrm{Cu}(\mathrm{II})$-amino alcohol derived complexes. J. Mol. Catal. A. 2015, 409, 85-93. [CrossRef]

40. Roeben, C.; Souto, J.A.; Gonzalez, Y.; Lishchynskyi, A.; Muniz, K. Enantioselective metal-free diamination of styrenes. Angew. Chem., Int. Ed. 2011, 50, 9478-9482. [CrossRef] [PubMed]

41. Sadhukhan, A.; Sahu, D.; Ganguly, B.; Khan, N.H.; Kureshy, R.I.; Abdi, S.H.R.S.; Bajaj, H.C. Oxazoline-based organocatalyst for enantioselective Strecker reactions: A protocol for the synthesis of levamisole. Chem. Eur. J. 2013, 19, 14224-14232. [CrossRef] [PubMed]

42. Kamal, A.; Ramesh Khanna, G.B.; Krishnaji, T.; Ramu, R. A new facile chemoenzymatic synthesis of levamisole. Biorg. Med. Chem. Lett. 2005, 15, 613-615. [CrossRef] [PubMed]

43. Shoeb, A.; Kapil, R.S.; Popli, S.P. Coumarins and alkaloids of Aegle-marmelos. Phytochemistry 1973, 12, 2071-2072. [CrossRef]

44. Das, A.; Choudhary, M.K.; Kureshy, R.I.; Roy, T.; Khan, N.H.; Abdi, S.H.R.; Bajaj, H.C. Enantioselective Henry and aza-Henry reaction in the synthesis of $(R)$-tembamide using efficient, recyclable polymeric CuII complexes as catalyst. ChemPlusChem 2014, 79, 1138-1146. [CrossRef]

45. Russo, A.; Lattanzi, A. Catalytic asymmetric beta-peroxidation of nitroalkenes. Adv. Synth. Catal. 2008, 350, 1991-1995. [CrossRef]

46. O'Brien, P.; Osborne, S.A.; Parker, D.D. Asymmetric aminohydroxylation of substituted styrenes: applications in the synthesis of enantiomerically enriched arylglycinols and a diamine. J. Chem. Soc. Perkin Trans. 1998, 1, 2519-2526. [CrossRef]

47. Watanabe, M.; Murata, K.; Ikariya, T. Practical synthesis of optically active amino alcohols via asymmetric transfer hydrogenation of functionalized aromatic ketones. J. Org. Chem. 2002, 67, 1712-1715. [CrossRef] [PubMed]

48. Soltani, O.; Ariger, M.A.; Vázquez-Villa, H.E.; Carreira, M. Transfer hydrogenation in water: enantioselective, catalytic reduction of alpha-cyano and alpha-nitro substituted acetophenones. Org. Lett. 2010, 12, 2893-2895. [CrossRef] [PubMed] 